\begin{tabular}{|l|l|l||}
\hline \multicolumn{2}{|c|}{ PublisherInfo } \\
\hline \hline PublisherName & $:$ & BioMed Central \\
\hline \hline PublisherLocation & $:$ & London \\
\hline \hline PublisherImprintName & $:$ & BioMed Central \\
\hline \hline
\end{tabular}

\title{
Musical twins
}

\begin{tabular}{|l|l|l||}
\hline \multicolumn{2}{|c|}{ ArticleInfo } \\
\hline \hline ArticleID & $:$ & 4010 \\
\hline \hline ArticleDOI & $:$ & $10.1186 /$ gb-spotlight-20010312-01 \\
\hline \hline ArticleCitationID & $:$ & spotlight-20010312-01 \\
\hline \hline ArticleSequenceNumber & $:$ & 81 \\
\hline \hline ArticleCategory & $:$ & Research news \\
\hline \hline ArticleFirstPage & $:$ & 1 \\
\hline \hline ArticleLastPage & $:$ & 2 \\
\hline \hline & & RegistrationDate : 2001-03-12 \\
ArticleHistory & $:$ & OnlineDate \\
\hline \hline ArticleCopyright & $:$ & BioMed Central Ltd2001 \\
\hline \hline ArticleGrants & $:$ & \\
\hline \hline ArticleContext & $:$ & 130592211 \\
\hline \hline
\end{tabular}




\section{Jonathan B Weitzman}

Email: jonathanweitzman@hotmail.com

Variations in individual pitch perception ability could be exploited to search for genes related to this complex musical trait. In the March 9 Science, Dennis Drayna and colleagues describe a large twin study aimed at determining the genetic contibutions to musical pitch recognition abilities (Science 2001, 291:1969-1972). Drayna et al used an updated 'distorted tunes test' (DTT) in which subjects listened to popular melodies and were asked to recognize notes inserted into these melodies that were of incorrect pitch. They tested female twin pairs (136 monozygotic, MZ, and 148 dizygotic, DZ) for pitch recognition ability, and applied genetic model-fitting techniques to ascertain the genetic and environmental contributions. They obtained a DTT correlation score of 0.67 for the MZ pairs, and 0.44 for the DZ pairs. The heritability was estimated at $71-80 \%$. The poor correlation between DTT scores and peripheral hearing abilities suggest that musical pitch recognition is independent of peripheral hearing and may use different physiological mechanisms.

\section{References}

1. Genetics tunes in.

2. Science, [http://www.sciencemag.org/]

3. Twins. Novel uses to study complex traits and genetic diseases.

4. On tune deafness (dysmelodia): frequency, development, genetics and musical background. 